\title{
REVIEWS
}

\section{SHANK proteins: roles at the synapse and in autism spectrum disorder}

\author{
Patricia Monteiro ${ }^{1,2,3,4}$ and Guoping Feng ${ }^{1,2}$
}

Abstract | Several large-scale genomic studies have supported an association between cases of autism spectrum disorder and mutations in the genes $\mathrm{SH} 3$ and multiple ankyrin repeat domains protein 1 (SHANK1), SHANK2 and SHANK3, which encode a family of postsynaptic scaffolding proteins that are present at glutamatergic synapses in the CNS. An evaluation of human genetic data, as well as of in vitro and in vivo animal model data, may allow us to understand how disruption of SHANK scaffolding proteins affects the structure and function of neural circuits and alters behaviour.

Intragenic promoters Promoters located within the body of the residing gene, regulating its activity. Intragenic promoters are mainly active in tissue-specific gene expression.
${ }^{\prime} M c$ Govern Institute for Brain Research, Department of Brain and Cognitive Sciences, Massachusetts Institute of Technology (MIT), Cambridge, Massachusetts 02139, USA. ${ }^{2}$ Stanley Center for Psychiatric Research, Broad Institute of Massachusetts Institute of Technology (MIT) and Harvard, Cambridge, Massachusetts 02142, USA. ${ }^{3}$ Life and Health Sciences Research Institute (ICVS), School of Health Sciences, University of Minho, 4704-553 Braga, Portugal. ${ }^{4}$ Life and Health Sciences Research Institute (ICVS)/3B's PT Government Associate Laboratory, University of Minho, Braga/Guimarães, 4710-057 Braga, Portugal. Correspondence to G.F. fengg@mit.edu
During development and throughout life, a number of dynamic processes regulate the number, size, shape and strength of neuronal synapses. These changes occur through alterations in the molecular composition of synapses and through the chemical modification of synaptic proteins ${ }^{1-4}$. However, sometimes, the genes encoding these synaptic proteins (such as those that encode $\mathrm{SH} 3$ and multiple ankyrin repeat domains protein 3 (SHANK3), neuroligin 3, neuroligin 4 or neurexin 1) carry particular mutations that result in the production of dysfunctional proteins that cannot fulfil their synaptic role. The consequences of such synaptic mutations often affect both protein structure and function, leading to synaptic and circuitry defects that may have a neurodevelopmental and neuropsychiatric impact.

Mutations in the SHANK (also known as ProSAP) family genes have been linked to syndromic and idiopathic autism spectrum disorder (ASD), as well as to other neuropsychiatric and neurodevelopmental disorders (schizophrenia and intellectual disability) $)^{5-8}$. In mice, mutations in the genes encoding SHANK family proteins (SHANK1, SHANK2 and SHANK3) often result in marked behavioural phenotypes. These include an increase in repetitive routines, altered social behaviour and anxiety-like phenotypes, seemingly similar to those described in some human neuropsychiatric disorders 9 .

Despite great research progress in establishing links between mutations in SHANK genes and ASD, the physiological role of SHANK proteins has, until recently, been poorly understood. Here, we review the most recent studies that help to clarify the roles of SHANK proteins at the synapse, providing insightful mechanistic links to neuropsychiatric disorders.

\section{The SHANK protein family}

SHANK proteins are 'master' scaffolding proteins that tether and organize intermediate scaffolding proteins. They are located at excitatory synapses, where they are crucial for proper synaptic development and function ${ }^{1,10}$. In the mouse, SHANK proteins are encoded by Shank1, Shank2 and Shank3 genes. Downstream from their transcription start sites, all three genes have alternative promoter options, resulting in the generation of a wide array of mRNA transcripts and protein isoforms.

SHANK3. SHANK3 (also known as ProSAP2) is the best studied of the three SHANK protein family members. The Shank3 gene is located on mouse chromosome 15E3 (human location: 22q13.3), has 22 exons and spans 60 kilobases of genomic DNA (FIG. 1). Shank3 has multiple intragenic promoters (probably six) ) $^{8,11,12}$ and several alternative splicing exons (exon 11, exon 12, exon 18, exon 21 and exon 22$)^{12}$, resulting in the possible generation of several protein isoforms (see Supplementary information S1 (figure)). Besides alternative promoter usage and mRNA splicing, Shank3 gene expression is regulated by epigenetic mechanisms such as DNA methylation and histone acetylation, causing tissue-specific expression of different SHANK3 isoforms ${ }^{13-15}$.

The full length structure of mouse SHANK3 contains six domains for protein-protein interactions: according to information contained in the databases UniProt Knowledgebase (UniProtKb) and National Center for Biotechnology Information (NCBI) database of the National Library of Medicine at the US National Institutes of Health (see Further information). These domains comprise protein domain of unknown function 535 (DUF535), ankyrin repeat domain, SRC homo$\operatorname{logy} 3$ (SH3) domain superfamily, postsynaptic density 

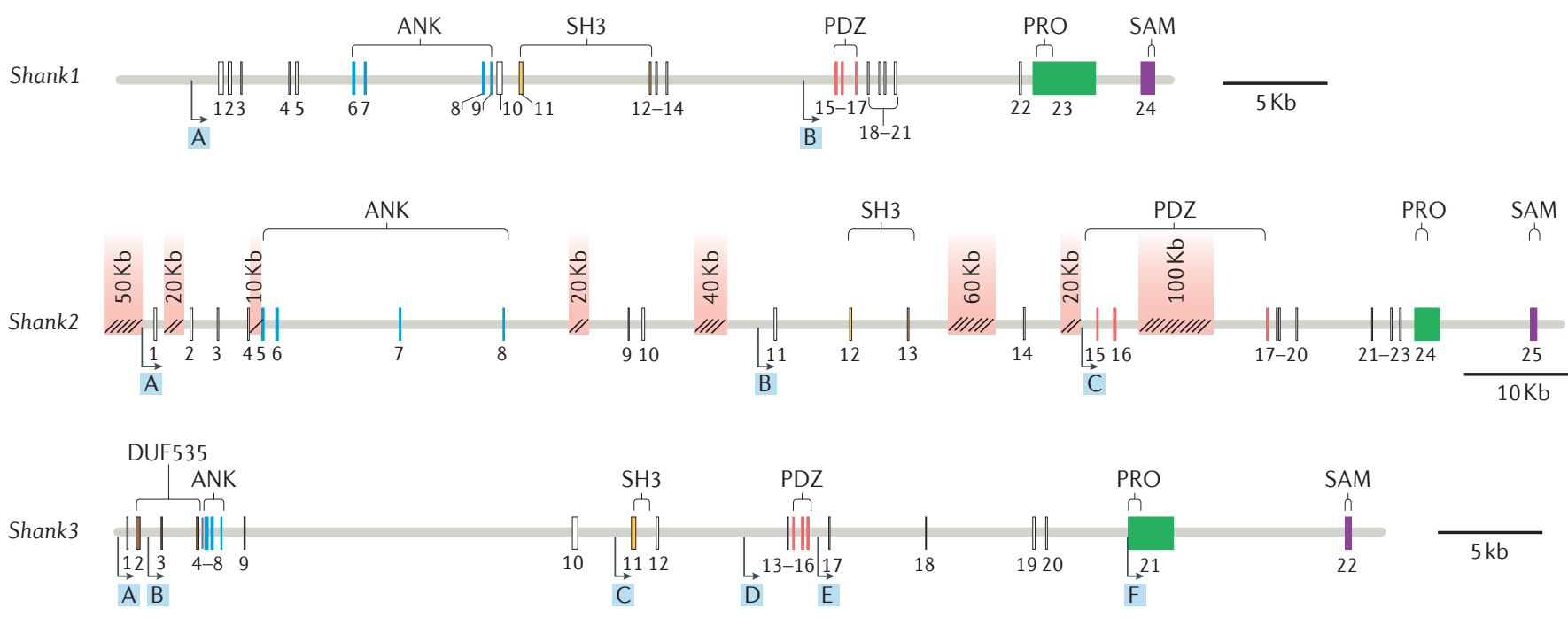

Figure 1 | Shank genes: structure and intragenic promoters. The schematics show the full structure of the mouse $\mathrm{SH} 3$ and multiple ankyrin repeat domains protein (Shank) genes and the location of intragenic promoters within these genes (in the figure, indicated by the arrows with letters in blue boxes). These structures have been drawn on the basis of the information contained at the National Center for Biotechnology Information (NCBI) database and UniProt Knowledgebase (UniProtKb). The location of the protein domains is included above their respective encoding exons (in the figure, exons are numbered and colour coded). Please note that, for the Shank2 gene, some intron sequences have been deleted for simplicity. Each intron deletion is represented by a break symbol of $10 \mathrm{~Kb}$, and the size of each total deletion in $\mathrm{Kb}$ is indicated above the respective break. ANK, ankyrin repeat domain; DUF535, protein domain of unknown function 535; PDZ, postsynaptic density protein 95-discs large homologue 1-zonula occludens 1 domain; PRO, proline-rich region; SAM, sterile alpha motif; SH3, SRC homology 3 domain superfamily.

Alternative splicing A process whereby different mRNAs can be produced from a single gene through the differential incorporation of exons into the mature transcript during splicing. Frequently, various mature proteins are generated from a single gene.

Epigenetic mechanisms A mechanism of a stable change in gene expression that does not involve changes in DNA sequence. protein 95 (PSD95)-discs large homologue 1-zonula occludens 1 (PDZ) domain, proline-rich region (PRO) and sterile alpha motif (SAM). The amino-terminal ankyrin repeat domain (containing six ankyrin repeats) interacts with the PSD protein SHARPIN ${ }^{16}$ and probably binds to the cytoskeleton through an interaction with spectrin alpha chain, non-erythrocytic 1 (SPTAN1; also known as $\alpha$-fodrin $)^{17}$. However, the $\mathrm{N}$-terminal region that precedes the ankyrin repeat domain interacts intramolecularly with the six ankyrin repeats and probably restricts the access to binding partners such as SHARPIN and SPTAN1 (REF. 18). The class I PDZ domain of SHANK3 interacts with SAP90/PSD95-associated protein 1 (SAPAP1; also known as GKAP1) $)^{10}$ and the glutamate receptor 1 (GluR1; also known as GRIA1) subunit of AMPA receptors (AMPARs) ${ }^{19}$, which is important for dendritic spine formation and synaptic transmission. The PRO domain binds to Homer ${ }^{20,21}$ and cortactin ${ }^{10}$ proteins, which are important for cytoskeleton regulation, synaptic transmission and plasticity. Last, the carboxy-terminal SAM domain of SHANK proteins is known to self-multimerize ${ }^{10,22}$ and is required for the localization of SHANK3 and SHANK2 to the PSD ${ }^{23}$. Besides all the aforementioned proteins, SHANKs have a number of other interaction partners ${ }^{8,24-27}$.

SHANK2. Shank2 (also known as ProSAP1) is the largest gene among Shank gene family members and is located on mouse chromosome 7F5 (human location: 11q13.2). It has 25 exons and spans about $450 \mathrm{~Kb}$ of mouse genomic DNA (FIG. 1). SHANK2 contains five domains: ankyrin repeat domain (located at the $\mathrm{N}$ terminus), SH3, PDZ, PRO and SAM (located at the $\mathrm{C}$ terminus) (FIG. 1). There are three isoforms of SHANK2 that are produced by alternative promoter usage: SHANK2E (containing all five protein domains), SHANK2A (lacking the ankyrin repeat domain) and SHANK2C (lacking the ankyrin repeat domain and the SH3 domain) (see Supplementary information S2 (figure)). Another isoform, SHANK2B, is transcribed from the same intragenic promoter as SHANK2A but shows alternative splicing. SHANK2E is the longest isoform of SHANK2 and is the only isoform that contains the ankyrin repeat domain (which is thought to coordinate actin-dependent events at the apical membrane of epithelial cells ${ }^{28}$ ). SHANK2E owes its name to the fact that it was initially thought to be expressed only in epithelial cells ${ }^{28}$; however, recent data suggest that SHANK2E is also expressed in human and mouse brain tissue, with high expression levels in the cerebellum ${ }^{29,30}$. Like SHANK3 and SHANK1, SHANK2 is a scaffolding protein of the PSD that interacts with multiple partners at the synapse ${ }^{10,20,24}$.

SHANK1. Shank1 is located on mouse chromosome 7B4 (human location: 19q13.33), has 24 exons and spans about $50 \mathrm{~Kb}$ of genomic DNA (FIG. 1). The gene contains two different promoters that can generate two different protein isoforms: SHANK1A (the longest isoform, which contains ankyrin repeat domain, $\mathrm{SH} 3, \mathrm{PDZ}, \mathrm{PRO}$ and SAM domains) and SHANK1B (which contains PDZ, PRO and SAM domains) (see Supplementary 
Concordance

The occurrence of a trait in both of two related individuals, such as twins or siblings. information S3 (figure)). Besides these two transcripts, which are produced by different promoters, Shank1 also contains alternative splicing sites that can generate different transcripts ${ }^{31}$. These include an isoform that lacks the C-terminal SAM domain, one that lacks the $\mathrm{N}$-terminal ankyrin repeat domain and the SH3 domain, and one that does not contain ankyrin repeat domain, $\mathrm{SH} 3$ or SAM domains (these isoforms were originally called SHANK1B, SHANK1C and SHANK1D, respectively ${ }^{31}$ ).

CNS expression patterns. The expression pattern of the three members of the SHANK protein family is slightly different in the rodent brain. For example, SHANK3 is the only family member that is highly enriched at corticostriatal glutamatergic synapses ${ }^{32}$. Shank1 mRNA seems to be exclusively expressed in the brain ${ }^{31}$ and is particularly enriched in the cortex, thalamus, amygdala, hippocampus (CA1 and CA3), dentate gyrus and in cerebellar Purkinje cells ${ }^{9,33,34}$. Shank2 mRNA is enriched in the cortex, thalamus, hippocampus (CA1 and CA3), dentate gyrus and in Purkinje cells ${ }^{9}$. It is also expressed in the kidney and liver, at lower levels ${ }^{31}$. Shank 3 mRNA is

a Shank genes in the mouse brain
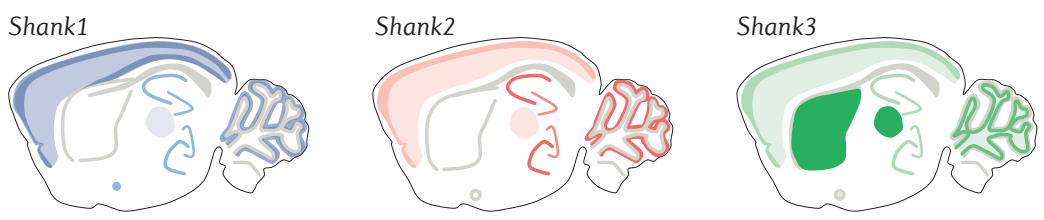

b SHANK3 isoforms in the mouse brain

\begin{tabular}{|c|c|c|c|c|c|}
\hline \multirow{2}{*}{$\begin{array}{l}\text { Brain region/ } \\
\text { cell type }\end{array}$} & \multicolumn{5}{|c|}{ SHANK3 isoform } \\
\hline & $3 A$ & $3 B$ & $3 C$ & $3 D$ & $3 E$ \\
\hline Striatum & Enriched & Low & Low & Low & Enriched \\
\hline Cortex & Present & Low & Low & Low & Present \\
\hline Hippocampus & Present & Low & Low & Low & Present \\
\hline Thalamus & Present & Low & Low & Low & Present \\
\hline Amygdala & Present & Low & Low & Low & Present \\
\hline Cerebellum & Low & Low & Enriched & Enriched & Low \\
\hline $\begin{array}{l}\text { Hippocampal } \\
\text { neuron }\end{array}$ & $\begin{array}{l}\text { Abundant } \\
\text { mRNA }\end{array}$ & $\begin{array}{l}\text { Abundant } \\
\text { mRNA }\end{array}$ & $\begin{array}{l}\text { Abundant } \\
\text { mRNA }\end{array}$ & $\begin{array}{l}\text { Abundant } \\
\text { mRNA }\end{array}$ & $\begin{array}{l}\text { Abundant } \\
\text { mRNA }\end{array}$ \\
\hline $\begin{array}{l}\text { Hippocampal } \\
\text { astrocyte }\end{array}$ & $\begin{array}{l}\text { Detectable } \\
\text { mRNA }\end{array}$ & $\begin{array}{l}\text { No mRNA } \\
\text { detected }\end{array}$ & $\begin{array}{l}\text { Detectable } \\
\text { mRNA }\end{array}$ & $\begin{array}{l}\text { Detectable } \\
\text { mRNA }\end{array}$ & $\begin{array}{l}\text { Detectable } \\
\text { mRNA }\end{array}$ \\
\hline
\end{tabular}

Figure 2 | Expression patterns of Shank genes and SHANK3 isoforms.

a | The schematics illustrate CNS expression pattern of $\mathrm{SH} 3$ and multiple ankyrin repeat domains protein (Shank) genes in the mouse brain. Each Shank gene is indicated by a different colour. Higher colour intensity represents a stronger expression signal (enriched areas). This part is created using data from REFS 9,11,31-34.b|The table details the expression pattern of different SHANK3 isoforms in the mouse brain. SHANK3B is expressed throughout the brain at low levels. SHANK3A and SHANK3E are enriched in the striatum and are present in the cortex, hippocampus, thalamus and amygdala. SHANK3C and SHANKD are mainly enriched in the cerebellum. SHANK3F is not represented, as no information on its expression is currently available. Hippocampal neurons strongly express all major isoforms of SHANK3, whereas astrocytes express low levels of SHANK3A, SHANK3C, SHANK3D and SHANK3E. Isoform expression pattern is extrapolated from REF. 11. highly expressed in the heart and moderately expressed in the brain and spleen ${ }^{31}$. In the brain, Shank 3 mRNA is enriched in the cortex, thalamus, striatum, hippocampus (more in CA3 than in CA1), dentate gyrus and in cerebellar granule cells ${ }^{9,35,36}$ (FIG. 2a).

The different SHANK3 protein isoforms are differently expressed according to developmental stage, cell type and brain region ${ }^{11,13,35,37}$ (FIG. 2b), suggesting the existence of isoform-specific functions. The different isoforms also present different subcellular localizations ${ }^{11}$. SHANK3B (an isoform lacking the PRO and SAM domains) localizes to the nucleus, whereas SHANK3A, SHANK3C and SHANK3E (isoforms containing the PRO and SAM domains) form clusters in the cytoplasm $^{11}$. This data thus suggest that PRO and SAM domains might be important for nuclear targeting of SHANK3 isoforms and that different subcellular localizations might contribute to the existence of isoformspecific functions. An important step for future research would be the generation of isoform-specific antibodies or probes that could enable a systematic analysis of isoform-specific binding partners and isoform-specific brain expression patterns. Understanding SHANK3 protein function from an isoform-specific perspective may also help to explain how different Shank3 gene mutations may result in distinct phenotypic consequences.

\section{Links between SHANK genes and ASD}

Currently, 1 in 88 children in the United States is diagnosed with ASD, with the prevalence being 4-5 times greater in boys than in girls ( 1 in 54 boys compared with 1 in 252 girls $)^{38,39}$. Other genetic conditions such as fragile $\mathrm{X}$ syndrome, tuberous sclerosis and Down syndrome are often associated with ASD. ASD diagnosis in the DSM-5 (Diagnostic and Statistical Manual of Mental Disorders, fifth edition ${ }^{40}$ ) is defined by social-communication and social-interaction deficits and narrow stereotyped, repetitive behavioural interests. These symptoms begin in early childhood and interfere with an individual's daily activities.

The biggest evidence for a genetic contribution to ASD comes from twin studies, which show $31 \%$ concordance rates for dizygotic twins and $88 \%$ for monozygotic twins ${ }^{41}$. ASDs are clinically heterogeneous, with symptom severity ranging from mild social deficits with normal cognitive abilities to severe mental impairment and absence of language skills. Evidence points towards the involvement of a number of distinct genetic variations (including chromosomal rearrangements, copy number variations and coding sequence variants) that have been associated with many different genes ${ }^{42,43}$. Despite this heterogeneity, many of the implicated genes encode synaptic proteins that have important roles in development or functioning of brain circuits (these include SHANK3, neuroligin 3, neuroligin 4 and neurexin 1$)^{44,45}$. Thus, the evidence suggests that, although ASDs are aetiologically heterogeneous (and the disorder may involve polygenic, monogenic and environmental factors), synaptic dysfunction might well be a common underlying mechanism for a defined subset of ASDs. 
Ring chromosomes

Structural aberrations of chromosomes, the long and short arms of which fuse together to form a ring. Ring chromosomes can have variable size and genetic content and are often associated with large terminal deletions.

Interstitial deletions The loss of one or more segments of DNA within a single chromosome (intra-chromosomal deletion). thereby joining genes that were previously far apart.

Unbalanced translocations Translocations are chromosomal abnormalities that are characterized by place exchange of parts of two or more different chromosomes Balanced translocations have no net loss or gain of any chromosomal material, whereas unbalanced translocations have unequal exchange of chromosomal material, hence resulting in loss or gain of extra genes.
SHANK genes were first implicated in neurodevelopmental disorders by studies of Phelan-McDermid syndrome (PMS), a neurodevelopmental disorder that is caused by a $22 \mathrm{q} 13.3$ deletion and is characterized by autistic-like behaviours, hypotonia and delayed or absent speech ${ }^{46-48}$. Genomic rearrangements in patients with PMS include deletions, ring chromosomes, interstitial deletions and unbalanced translocations ${ }^{5,49}$. SHANK3 is deleted in nearly all reported cases of PMS ${ }^{50,51}$, and its disruption is therefore thought to cause the core neurodevelopmental and behavioural deficits that are seen in patients. Supporting the idea that core PMS symptoms are due to SHANK3 haploinsufficiency ${ }^{46}$, individuals carrying a ring chromosome 22 in which the SHANK3 gene is intact are phenotypically normal.

Apart from the syndromic forms of autism (such as PMS, in which SHANK3 disruption may be responsible for the core phenotype), many SHANK3 mutations have also been identified in genetic screenings of patients with ASD who have not been diagnosed with PMS ${ }^{5-7,52,53}$ (TABLE 1; see Supplementary information S4 (table)). These mutations include microdeletions, nonsense mutations, breakpoints and missense mutations. In addition, mutations in SHANK1 and SHANK2 have also been recently associated with ASD cases ${ }^{5,8,12,25,54}$. A metaanalysis study found that mutations or disruptions in the SHANK gene family account for $\sim 1 \%$ of all patients with $\mathrm{ASD}^{5}$. There is also a correlation between SHANK1-3 mutations and the degree of cognitive impairment: patients with SHANK3 mutations have more-severe cognitive deficits than those with SHANK1 or SHANK2 mutations ${ }^{5}$. Together these findings indicate that a common neurobiological role, shared by all SHANK gene family members, may be of relevance to ASD pathophysiology and that the degree of cognitive impairment in ASD may depend on which SHANK family member is mutated. The difference in impairment severity might be explained by the expression pattern of the particular SHANK gene that is mutated and by the extent to which the other two remaining SHANK members can (or cannot) compensate for its loss. In addition, these findings indicate that mutations in SHANK genes are a potential monogenic cause for ASD and indicate that several SHANK mutations are of a syndromic nature and should be considered for screening in clinical practice ${ }^{5}$. Last, it is worth noting that many of the human SHANK3 mutations map to exon 21 and are associated with moderate to severe intellectual disability ${ }^{5}$. It is currently unclear how mutations in the PRO domain of exon 21 might be related to the pathophysiology. One possible explanation is that exon 21 is present in most SHANK3 isoforms; thus, mutations in this exon are likely to affect the expression and/or function of a large proportion of the SHANK3 proteins that are produced.

Given the potential importance of these genes in ASD, it is crucial to understand more about their normal roles at the synapse and how they are disrupted by mutations.

Table 1 | Human SHANK3 mutations and small deletions

\begin{tabular}{|c|c|c|c|c|}
\hline $\begin{array}{l}\text { Exon and domain } \\
\text { affected by mutation }\end{array}$ & $\begin{array}{l}\text { Total number of cases } \\
\text { across studies }\end{array}$ & Diagnoses & Phenotypes and comments & Refs \\
\hline Exon 21; PRO & 11 & $\begin{array}{l}\text { ASD ( } 7 \text { cases), } \\
\text { PDD-NOS ( } 1 \text { case), } \\
\text { schizophrenia ( } 3 \text { cases) }\end{array}$ & $\begin{array}{l}\text { - Severe ID (8 cases); mild-moderate ID (3 cases) } \\
\text { - Non-verbal (4 cases); severely impaired speech (2 cases) } \\
\text { - Global developmental delay (6 cases) } \\
\text { - Hypotonia ( } 3 \text { cases); ataxia and dysmetria (1 case) } \\
\text { - Cycling vomiting (1 case); gastroesophageal reflux (2 cases) } \\
\text { - Epilepsy (2 cases) }\end{array}$ & $\begin{array}{r}5,7 \\
53,83\end{array}$ \\
\hline $\begin{array}{l}\text { Intron } 15 \text {-exon } 16 \\
\text { boundary }\end{array}$ & 1 & Asperger syndrome & Behavioural problems and echolalia at the age of 2 years & 7 \\
\hline Exon 8; ANK & 2 & ASD & $\begin{array}{l}\text { - Repetitive behaviours and circumscribed interests } \\
\text { - Generalized hypotonia and brisk reflexes } \\
\text { - Impaired verbal communication and social interaction } \\
\text { - Abnormal EEG }\end{array}$ & 52,53 \\
\hline
\end{tabular}

Please note that this table does not cover all known mutations. For other human $\mathrm{SH} 3$ and multiple ankyrin repeat domains protein 3 (SHANK3) mutations and deletions, see REFS 5,12. A more detailed table is provided as Supplementary information S4 (table). ANK, ankyrin repeat domain; ASD, autism spectrum disorder; ASQ, Autism Screening Questionnaire (a score higher than 15 indicates ASD); EEG, electroencephalography; ID, intellectual disability; NRXN1, neurexin 1; PDD-NOS, pervasive developmental disorder, not otherwise specified; PRO, proline-rich region; SH3, SRC homology 3 domain superfamily. 
Microdeletions

Small interstitial deletions of DNA (up to $5 \mathrm{Mb}$ ).

\section{Breakpoints}

The specific sites of chromosomal breakage that are associated with a particula chromosomal rearrangement.

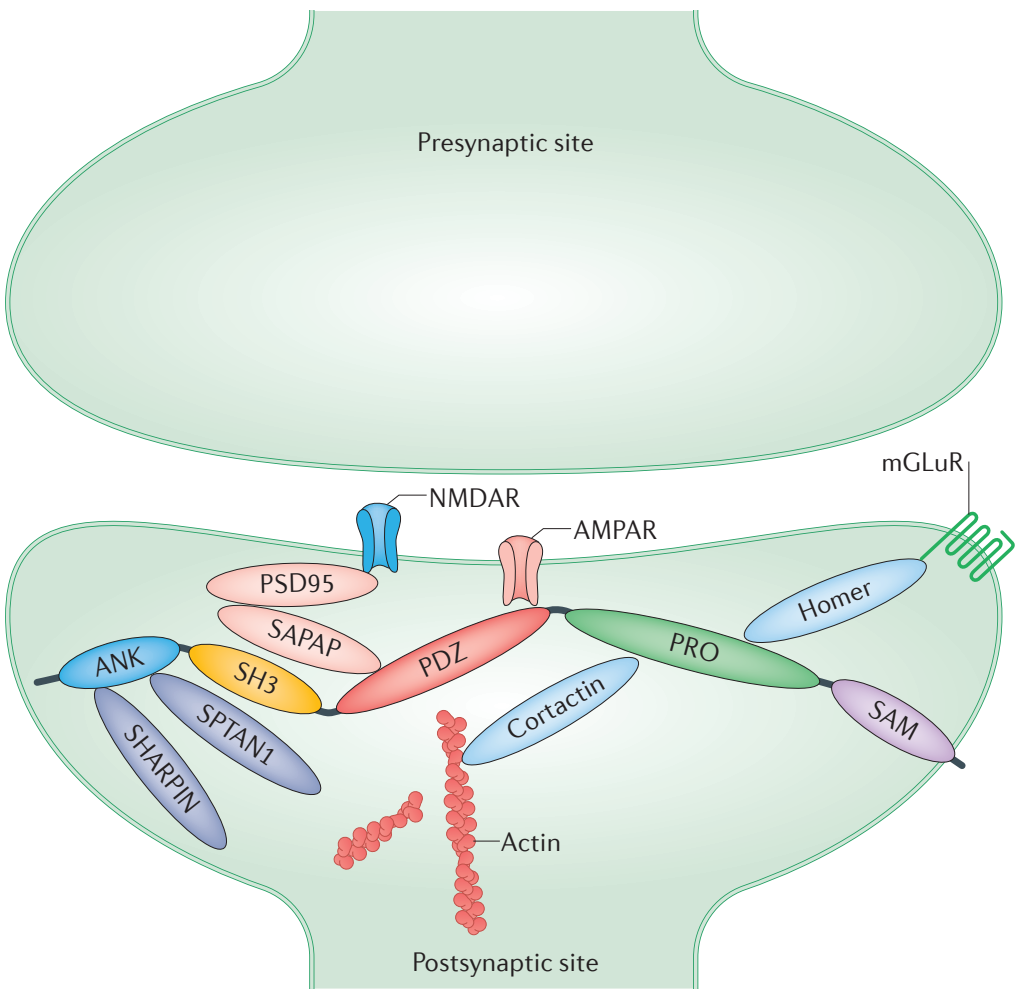

Figure 3 | SHANK-interacting proteins in the postsynaptic site. A representation of a SH3 and multiple ankyrin repeat domains protein (SHANK) located in the postsynaptic density (PSD) is shown, with its protein-protein interaction domains illustrated. The $\mathrm{N}$-terminal ankyrin repeat domain (ANK) interacts with the PSD protein SHARPIN and probably binds to the cytoskeleton through an interaction with spectrin alpha chain, non-erythrocytic 1 (SPTAN1). The PSD protein 95 (PSD95)-discs large homologue 1zonula occludens 1 (PDZ) domain interacts with SAP90/PSD95-associated proteins (SAPAPs) and the glutamate receptor 1 (GluR1) subunit of AMPA receptors (AMPARs). SAPAPs bind to PSD95, which then interacts with NMDA receptors (NMDARs). The proline-rich domain (PRO) binds to Homer (which binds to metabotropic GluRs (mGLuRs)) and cortactin proteins (which interact with actin and are important for cytoskeleton regulation). Last, the C-terminal sterile alpha motif (SAM) of SHANK proteins is known to self-multimerize and is required for the localization of SHANK proteins to the PSD. SH3, SRC homology 3 domain superfamily.
DLG4), SAP102 (also known as DLG3), SAP97 (also known as DLG1) and PSD93 (also known as chapsyn 110 or DLG2). Together, these family members build up a dense scaffold that serves as interface between clustered membrane-bound receptors, cell adhesion molecules and the actin cytoskeleton ${ }^{57}$. The identification of MAGUK proteins, and the subsequent cloning of their associated proteins, has extended our comprehension of the molecular composition of the PSD ${ }^{1,57,58}$.

PSD95 is probably the best characterized MAGUK protein of the PSD. It has a PDZ domain that interacts with NMDARs and a guanylate kinase domain in its $\mathrm{C}$ terminus that is linked to members of the SAPAP family of proteins. SAPAP proteins subsequently bind to the PDZ domain of members of the SHANK protein family. SHANK proteins then bind to the actin cytoskeleton and to Homer protein, which in turn interacts with mGluRs. Through these extended links, PSD95, SAPAP, SHANK and Homer proteins form a quaternary complex that brings together mGluR and NMDAR complexes in the PSD (FIG. 3). This functional link between NMDARs and mGluRs is likely to facilitate crosstalk between ionotropic and metabotropic glutamate receptors ${ }^{59}$.

On a subcellular level, SHANK proteins are located in a distal area of the PSD that extends up to $120 \mathrm{~nm}$ away from the postsynaptic membrane ${ }^{10,60}$. Recent data suggest that there are two pools of SHANK proteins in the PSD complex: one that is closer to the postsynaptic membrane and that seems to be relatively stable and able to bind to SAPAPs, and another, more dynamic, pool that is present at a distal location and probably cannot interact with SAPAPs ${ }^{61}$.

Consistent with the roles of SHANK proteins as major scaffolding proteins in the postsynaptic site, the deletion of Shank genes in mice alters the PSD levels of several proteins including Homer, SAPAP proteins, NMDARs and AMPARs ${ }^{9,37}$. Parallel to these molecular alterations, morphological and functional changes have also been found in several Shank-mutant mice. Depending on which Shank gene is mutated and on the specific nature of the mutation, many other functional and behavioural consequences can be seen. These include impaired social behaviours, self-grooming and synaptic plasticity defects ${ }^{9,30,36,37,62-68}$ (for a detailed comparison between Shank1-, Shank2- and Shank3-mutant mice, see REFS 8,12). Deletion of Shank genes also affects spine numbers and size ${ }^{37,66,69,70}$, as well as AMPA transmission (with effects on miniature excitatory postsynaptic current (mEPSC) frequency and amplitude being observed $)^{9,36,37,66,71}$. The different mutant mice thus indicate an important role of SHANK proteins in regulating excitatory neurotransmission.

Owing to the strong genetic association between SHANK3 mutations and ASD (see above), many neurobiology studies have focused on this particular gene. Shank3-knockout (Shank3-KO) mice display reduced corticostriatal connectivity and reduced striatal mEPSC frequency in adults $9,36,37,66$. This suggests that loss of Shank 3 decreases the number of striatal afferents that are formed during development (resulting in a reduced number of corticostriatal synapses); however, recent electrophysiological data obtained at postnatal day 14 
reveal that Shank3-KO mice actually exhibit increased striatal mEPSC frequency in early development ${ }^{71}$. These results indicate that there is a premature increase in (and subsequent arrest of) the development of excitatory afferents onto striatal neurons in the absence of SHANK3 (REF. 71). Given this reduction in basal excitatory synaptic transmission, one could mistakenly assume that there is reduced activity in the striatum of Shank3-KO mice. In fact, Shank3-KO mice have increased in vivo activity in the striatum ${ }^{36,71}$. This striatal hyperactive profile does not seem to be due to increased intrinsic excitability of striatal neurons but rather to be a downstream consequence of increased cortical activity ${ }^{71}$. The mechanism behind the cortex hyperexcitability profile in the absence of SHANK3 is currently not known.

Corroborating these in vivo mouse studies, recent in vitro data also show increased frequency of evoked firing in cultured neurons from Shank3-KO mice ${ }^{72}$, as well as similar changes in cultured human neurons differentiated from induced pluripotent stem cells that are derived from the cells of patients with $\mathrm{PMS}^{72,73}$. Although these studies have focused on excitatory transmission (owing to the location of SHANK3 at excitatory synaptic sites), it is important to keep in mind that Shank3 deletion may also affect inhibitory synaptic transmission. Indeed, recent data show reduced numbers of synaptic puncta containing parvalbumin (PV; an interneuron marker in the cortex) and compromised wisteria floribunda agglutinincontaining perineuronal nets that have reduced size and intensity in the insular cortex ${ }^{74}$, as well as reduced PV expression in the striatum ${ }^{75}$. In the cortex, perineuronal nets preferentially enwrap large PV-containing interneurons. Therefore, when perineuronal nets are disrupted, the perisomatic inhibition of the targets of these interneurons is reduced. This indicates an immature or altered inhibitory circuitry in Shank3-KO mice. In line with these data, a different study found that the abnormal network firing pattern that is seen in cultured cortical neurons of Shank3-KO mice can be normalized by application of clonazepam, an enhancer of GABAmediated inhibitory transmission ${ }^{76}$. Taking a different approach $^{35}$, it has also been shown that mice carrying a deletion in Shank3 exon 9 have an increased excitation/ inhibition (E/l) ratio in the medial prefrontal cortex (mPFC). Although these mice have decreased miniature inhibitory postsynaptic currents (mIPSC) frequency in $\mathrm{mPFC}$ layer 2/3 pyramidal neurons, they display increased mIPSC frequency in hippocampus CA1 pyramidal neurons. Together, these studies suggest a developmental arrest of neural circuits in the absence of SHANK3, with consequent disruption of optimal E/I circuitry balance ${ }^{77}$.

Given the wide array of synaptic roles of SHANK3 that are demonstrated by these studies (ranging from scaffolding to regulating spine morphology and neurotransmission), it will be important to understand which role is the most significant with regard to ASD.

\section{Neurobiology of SHANK proteins in ASD}

As noted above, several human genetic studies have pointed towards a link between mutations in SHANK1, SHANK2 or SHANK3 and ASD ${ }^{5,78}$. Although ASD neuropathology remains elusive, animal models based on mice carrying relevant genetic mutations may help us to dissect the circuit basis of behaviours that are evolutionary conserved and relevant to ASD. Several behavioural abnormalities have been reported in mice with deletions in Shank genes, some of which are considered ASD-like behaviours ${ }^{9,30,62-65,67,68}$. Thirteen different mutant mouse lines carrying Shank3 deletions have been generated so far (TABLE 2; see Supplementary information S5 (table)). Of these, 9 of 13 mutant lines show aberrant social behaviours (1 line has not been tested for these behaviours), and 9 of 13 display repetitive self-grooming behaviour (TABLE 2). Self-injurious grooming is usually observed after complete Shank3 deletion ${ }^{71}$ and after Shank3 PDZtargeted disruption ${ }^{9,37,66}$. A key challenge is therefore to understand how the disrupted synaptic function of SHANK3 can lead to these behavioural changes.

Social interaction requires the ability to combine sensory information with emotional and cognitive content $^{79}$. Many brain areas have been implicated as part of the 'social brain', including the mPFC, the amygdala, the anterior insula, the anterior cingulate cortex, the inferior frontal gyrus and the superior temporal sulcus ${ }^{80-82}$. A recent study of the mouse insular cortex found multisensory integration deficits in Shank3-mutant mice and suggested that altered GABA circuits in the insular cortex may underlie the asocial urges of these mice ${ }^{74}$.

Other behavioural parameters, such as ultrasonic vocalizations and learning and memory, have been evaluated in some of the different Shank3-mutant lines, revealing distinct results that might be related to isoform-specific disruptions in each line (TABLE 2). Indeed, the idea that isoform-specific disruptions will result in different phenotypic consequences (and even result in different disorders) has recently gained momentum. A recent study ${ }^{66}$ generated two novel Shank3-mutant mouse lines harbouring Shank3 mutations that are found in patients with $\mathrm{ASD}^{53}$ and schizophrenia ${ }^{83}$, respectively. Both mutations are located in exon 21 of the mouse Shank3 gene, and the mutations are located only 325 nucleotides apart. The ASD-linked InsG3680 mutation has a guanine nucleotide insertion at position 3680 of Shank3 cDNA, resulting in a frameshift mutation and the appearance of a stop codon immediately after the mutation. The schizophrenia-linked R1117X mutation, on the other hand, changes arginine 1117 to a stop codon. These two mutant mouse lines exhibit both distinct and shared defects at molecular, synaptic, circuit and behavioural levels ${ }^{66}$. Whereas mice with the ASD-linked mutation display impaired striatal synaptic transmission at postnatal day 14 and abnormal juvenile social interactions (similar to the early-age onset of ASD symptoms), adult mice with the schizophrenia-linked mutation have profound synaptic defects in the PFC and display social dominance behaviour. Given that the ASD-linked mutation results in almost complete loss of SHANK3 (similar to a full deletion of the Shank3 gene) and that the schizophrenia-linked mutation results in the generation of a truncated SHANK3 protein (which could be either partially functional or act as a dominant negative), this study provides, for the first time, some 
Table 2 | Characterization of the different Shank3-mutant mice

\begin{tabular}{|c|c|c|c|c|c|c|c|c|c|}
\hline \multirow{2}{*}{$\begin{array}{l}\text { Protein } \\
\text { domain/ } \\
\text { exon } \\
\text { mutated }\end{array}$} & \multicolumn{8}{|c|}{ Phenotype } & \multirow[t]{2}{*}{ Refs } \\
\hline & $\begin{array}{l}\text { Altered } \\
\text { synaptic } \\
\text { proteins }\end{array}$ & $\begin{array}{l}\text { Spine } \\
\text { morphology }\end{array}$ & $\begin{array}{l}\text { Social } \\
\text { behaviour }\end{array}$ & USVs & $\begin{array}{l}\text { Repetitive } \\
\text { behaviours }\end{array}$ & $\begin{array}{l}\text { Learning } \\
\text { and } \\
\text { memory }\end{array}$ & $\begin{array}{l}\text { Motor } \\
\text { coordination }\end{array}$ & Other & \\
\hline \multirow[t]{3}{*}{$\begin{array}{l}\text { ANK; exons } \\
4-9\end{array}$} & GluR1 & $\begin{array}{l}\text { Defective } \\
\text { remodelling }\end{array}$ & $\begin{array}{l}\text { Reduced } \\
\text { sniffing }\end{array}$ & Reduced & $\begin{array}{l}\text { Increased } \\
\text { self-grooming }\end{array}$ & $\begin{array}{l}\text { MWM test } \\
\text { normal }\end{array}$ & Impaired & $\begin{array}{l}\text { NOR test } \\
\text { impaired }\end{array}$ & $\begin{array}{r}63 \\
64\end{array}$ \\
\hline & $\begin{array}{l}\text { SAPAP1, } \\
\text { Homer } 1 \mathrm{~b} / \mathrm{c}, \\
\text { GluR1 and } \\
\text { GluN2A }\end{array}$ & $\begin{array}{l}\text { Reduced } \\
\text { density }\end{array}$ & $\begin{array}{l}\text { Abnormal } \\
\text { interactions }\end{array}$ & Altered & $\begin{array}{l}\text { Increased } \\
\text { self-grooming } \\
\text { and head } \\
\text { pokes in } \\
\text { hole-board } \\
\text { test }\end{array}$ & $\begin{array}{l}\text { MWM test } \\
\text { impaired }\end{array}$ & Impaired & $\begin{array}{l}\text { Reduced } \\
\text { distance in OF } \\
\text { test; NOR test } \\
\text { impaired }\end{array}$ & 62 \\
\hline & $\begin{array}{l}\text { GluR2, GluR3, } \\
\text { Homer 1b/c and } \\
\text { PSD95 }\end{array}$ & NA & $\begin{array}{l}\text { Mild } \\
\text { impairment }\end{array}$ & Increased & $\begin{array}{l}\text { Increased } \\
\text { self-grooming }\end{array}$ & $\begin{array}{l}\text { MWM test } \\
\text { slightly } \\
\text { impaired }\end{array}$ & NS & $\begin{array}{l}\text { NOR test } \\
\text { impaired }\end{array}$ & 101 \\
\hline $\begin{array}{l}\text { ANK; exons } \\
4-7\end{array}$ & NA & NA & $\begin{array}{l}\text { Abnormal } \\
\text { social } \\
\text { novelty }\end{array}$ & NA & $\begin{array}{l}\text { No increase in } \\
\text { self-grooming }\end{array}$ & NA & NA & NA & 9 \\
\hline $\begin{array}{l}\text { ANK; exon } \\
9\end{array}$ & NA & NA & Normal & Normal & $\begin{array}{l}\text { Increased } \\
\text { rearing } \\
\text { in novel } \\
\text { environment }\end{array}$ & Normal & NA & None & 35 \\
\hline \multirow[t]{2}{*}{$\begin{array}{l}\text { PDZ; exons } \\
13-16\end{array}$} & $\begin{array}{l}\text { Homer 1, } \\
\text { SAPAP3, } \\
\text { GluN2A, } \\
\text { GluN2B, GluR2 } \\
\text { and PSD93 }\end{array}$ & $\begin{array}{l}\text { Reduced } \\
\text { density }\end{array}$ & Abnormal & NA & $\begin{array}{l}\text { Self-injurious } \\
\text { grooming }\end{array}$ & Normal & NA & $\begin{array}{l}\text { Increased } \\
\text { anxiety-like } \\
\text { behaviour }\end{array}$ & 9 \\
\hline & $\begin{array}{l}\text { Homer } 1, \\
\text { SAPAP3, } \\
\text { GluN2A, GluN2B } \\
\text { and GluR2 }\end{array}$ & $\begin{array}{l}\text { Reduced } \\
\text { density }\end{array}$ & Abnormal & NA & $\begin{array}{l}\text { Self-injurious } \\
\text { grooming }\end{array}$ & NA & Impaired & $\begin{array}{l}\text { Increased } \\
\text { anxiety-like } \\
\text { behaviour }\end{array}$ & 37 \\
\hline $\begin{array}{l}\text { SH3; exon } \\
11\end{array}$ & $\begin{array}{l}\text { GluN2B, } \\
\text { SHANK2, } \\
\text { Homer 1b/c and } \\
\text { mGluR5 }\end{array}$ & Normal & Abnormal & NA & $\begin{array}{l}\text { Self-injurious } \\
\text { grooming }\end{array}$ & $\begin{array}{l}\text { MWM test } \\
\text { impaired }\end{array}$ & Minor deficits & $\begin{array}{l}\text { Hyposensitivity; } \\
\text { impaired } \\
\text { nesting and } \\
\text { marble burying; } \\
\text { increased } \\
\text { aggression }\end{array}$ & $\begin{array}{r}30 \\
98\end{array}$ \\
\hline \multirow[t]{3}{*}{$\begin{array}{l}\text { PRO; exon } \\
21\end{array}$} & mGluR5 & Normal & $\begin{array}{l}\text { Abnormal } \\
\text { social } \\
\text { novelty }\end{array}$ & NA & $\begin{array}{l}\text { Increased } \\
\text { self-grooming }\end{array}$ & $\begin{array}{l}\text { MWM test } \\
\text { impaired }\end{array}$ & Impaired & $\begin{array}{l}\text { Hypersensitivity; } \\
\text { impaired } \\
\text { nesting and } \\
\text { marble burying; } \\
\text { anxiety-like } \\
\text { behaviour }\end{array}$ & 65 \\
\hline & $\begin{array}{l}\text { p-GluN2B } \\
\text { Tyr1472 }\end{array}$ & NA & $\begin{array}{l}\text { Inconclusive } \\
\text { testing }\end{array}$ & NA & None & $\begin{array}{l}\text { MWM } \\
\text { test mildly } \\
\text { impaired }\end{array}$ & Impaired & $\begin{array}{l}\text { Impaired } \\
\text { nesting and } \\
\text { marble burying; } \\
\text { anxiety-like } \\
\text { behaviour }\end{array}$ & 102 \\
\hline & $\begin{array}{l}\text { Homer proteins, } \\
\text { SAPAP3, } \\
\text { SYNGAP, } \\
\text { GluN1, GluN2A, } \\
\text { GluN2B, GluR2 } \\
\text { and mGluR5 }\end{array}$ & $\begin{array}{l}\text { Reduced } \\
\text { number }\end{array}$ & Abnormal & Normal & $\begin{array}{l}\text { Self-injurious } \\
\text { grooming }\end{array}$ & NA & Impaired & $\begin{array}{l}\text { Anxiety-like } \\
\text { behaviour; PPI } \\
\text { test impaired; } \\
\text { startle-response } \\
\text { impaired }\end{array}$ & 66 \\
\hline $\begin{array}{l}\text { All } \\
\text { domains; } \\
\text { exons 4-22 }\end{array}$ & $\begin{array}{l}\text { Pan-SAPAP, } \\
\text { SAPAP3 and } \\
\text { Homer } 1 \mathrm{~b} / \mathrm{c}\end{array}$ & $\begin{array}{l}\text { Reduced in } \\
\text { the striatum }\end{array}$ & Normal & $\begin{array}{l}\text { Altered } \\
\text { spectral } \\
\text { properties }\end{array}$ & $\begin{array}{l}\text { Self-injurious } \\
\text { grooming }\end{array}$ & $\begin{array}{l}\text { MWM test } \\
\text { impaired }\end{array}$ & Impaired & $\begin{array}{l}\text { Anxiety-like } \\
\text { behaviour; PPI } \\
\text { test impaired; } \\
\text { impaired } \\
\text { instrumental } \\
\text { learning }\end{array}$ & 36 \\
\hline
\end{tabular}

A more detailed table is provided as Supplementary information S5 (Table). ANK, ankyrin repeat domain; GluR1, glutamate receptor 1; mGluR5, metabotropic GluR5; Homer 1b/c, Homer splice variants $1 \mathrm{~b}$ and 1c; MWM, Morris water maze; NA, not available; NOR, novel-object recognition; NS, nonsignificant; OF, open field; p-GluN2B Tyr1472, phosphorylated Tyr1472 site of GluN2B; PDZ, postsynaptic density protein 95 (PSD95)-discs large homologue 1-zonula occludens 1 domain; PPI, prepulse inhibition; PRO, proline-rich region; SAPAP1, SAP90/PSD95-associated protein 1; SH3, SRC homology 3 domain superfamily; SHANK2, SH3 and multiple ankyrin repeat domains protein 2; USVs, ultrasonic vocalizations. 
neurobiological insights into how different mutations in the Shank3 gene may lead to mutation-specific defects and contribute to different disorders.

Besides isoform-specific mutations, SHANK3 gene expression (or perhaps expression of specific isoforms) seems to be crucial. For example, duplications of 22q13 that span SHANK3 have been reported in patients diagnosed with attention deficit hyperactivity disorder $(\mathrm{ADHD})^{52}$, and mice in which SHANK3 is overexpressed exhibit synaptic dysfunction and manic-like phenotypes ${ }^{84}$.

Mutant mice carrying Shank1 and Shank2 deletions have also been generated and characterized in recent years $^{67,85-87,68,88,30,89}$ (TABLE 3; see Supplementary information S6 (table)). In line with the human genetic data that showed an association between different SHANK family members and distinct cases of $\mathrm{ASD}^{5}$, all three lines of mutant mice carrying Shank1 and Shank2 deletions display certain ASD-like phenotypes, such as increased repetitive behaviour and/or decreased social interaction ${ }^{30,67,68}$. A recent study reveals that, besides regulating excitatory synaptic transmission in neurons ${ }^{67}$, SHANK1 also regulates excitatory synaptic transmission in inhibitory interneurons ${ }^{86}$. The study further confirms the expression of all three Shank genes in CA1 PV-expressing interneurons and suggests that, in the absence of Shank1, a shift occurs in the E/I balance of the hippocampus. As a consequence, PV-expressing interneurons receive less excitatory input and provide weaker inhibitory output onto CA1 pyramidal neurons. Interestingly, no major changes were found in CA1 inhibitory synapses in Shank2-mutant mice with regard to inhibitory transmission ${ }^{30}$ or protein markers ${ }^{68}$.

Although the different Shank1-, Shank2- and Shank3-mutant mice have some distinct phenotypes at the molecular and functional level, they all feature a disrupted E/I balance that results from initial changes in excitatory synaptic transmission and composition, as well as ASD-relevant behavioural phenotypes ${ }^{30,67,68}$. Taken together, the findings from different Shank-mutant mice suggest that each Shank mutation might underlie a defined subset of ASD pathology and contribute to the myriad of phenotypes that are seen in patients.

\section{Towards the development of treatment}

Given the complex genomic landscape of human mutations that are associated with ASD, animal models pose a starting point to study the neurobiology of specific mutations and establish useful genotype-cellular phenotype correlations. The SHANK3 gene, in particular, has the advantage of having available 13 difference mice models, harbouring different Shank3 gene disruptions. The gene itself is probably also less complicated to study than some other ASD-related genes because of the defined localization of SHANK3 protein at glutamatergic synapses. This has advantages over the study of a transcription factor, such as methyl-CpG-binding protein 2 (MeCP2), which may directly regulate the expression of hundreds of genes. Because ASDs are neurodevelopmental disorders (patients typically display symptoms before the age of three $)^{90,91}$, one of the key questions in autism research is whether the pathology is reversible in adults. Recently, this question was tackled in a study that generated a Shank 3 conditional knock-in mouse ${ }^{37}$. These mice are born as Shank3-KO (carrying a PDZ domain deletion) but have a FLExed PDZ domain inverted, which allows reorientation at any time point in life to restore the Shank3 gene. This strategy design is crucial because it keeps the Shank3 gene under the control of its endogenous genomic locus and avoids SHANK3 expression at non-physiological levels that could induce potential confounds. These Shank3-KO mice have deficits in striatal neurotransmission, reduced spine density in the striatum and reduced levels of PSD proteins (SAPAP3, Homer, GluN2A, GluN2B and GluR2) in the striatum. All these alterations can be reverted in the adult by restoring the Shank3 gene. Behaviourally, these Shank3-KO

Table 3 | Characterization of the different Shank1- and Shank2-mutant mice

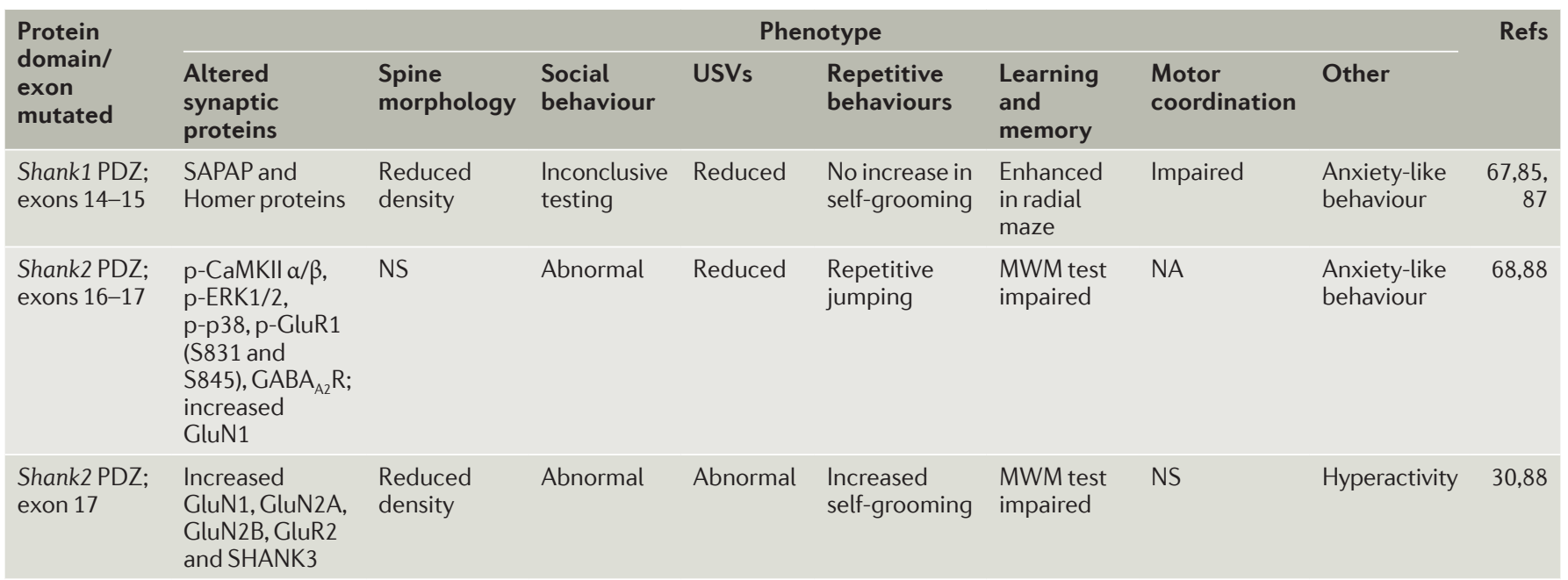

A more detailed table is provided as Supplementary information S6 (table). GABA ${ }_{A 2} \mathrm{R}, \mathrm{GABA}$ type A2 receptor; MWM, Morris water maze; NA, not available; NS, nonsignificant; $p$-CaMKII $\alpha / \beta$, phosphorylated calcium/calmodulin-dependent protein kinase type II subunit alpha/beta; $p$-ERK1/2, phosphorylated extracellular signal-regulated kinases 1 and 2; p-GluR1, phosphorylated glutamate receptor 1; PDZ, postsynaptic density protein 95 (PSD95)-discs large homologue 1-zonula occludens 1 domain; SAPAP, SAP90/PSD95-associated protein; Shank1, SH3 and multiple ankyrin repeat domains protein 1; USVs, ultrasonic vocalizations. 
mice display repetitive self-injurious grooming, anxiety, social-interaction deficits (reduced social-interaction frequency and duration) and impaired motor coordination. After adult restoration of Shank3 expression, repetitive self-injurious grooming and social-interaction deficits, but not anxiety or motor coordination deficits, can be rescued, indicating a selective rescue of certain autismlike phenotypes. The same study shows that the behavioural deficits that are irreversible in adulthood can be improved by early postnatal intervention, highlighting the unique behavioural effects of SHANK3 expression during specific developmental periods and throughout life. Given the emergence of new genome editing approaches (such as CRISPR), these results suggest that repair of the SHANK3 gene in adulthood could alleviate some of the synaptic and behavioural impairments that are associated with SHANK3 mutations. Although there are still technical limitations to the genetic manipulation of mature neurons in a fully formed brain, new studies have been pushing the boundaries of the use of CRISPR in adult brain repair ${ }^{92}$. More importantly, this study suggests the possibility of treatment (whether pharmacological or through future genetic repair approaches) for patients with SHANK3 mutations or deletion, during adulthood. Similar encouraging adult-rescue results have been reported for mutant mice carrying deletions and duplications in other ASD-related genes such as Mecp2 (REFS 93-95) and ubiquitin-protein ligase E3A (Ube3a) ${ }^{96}$.

Other studies have taken a different approach towards reversing the phenotype resulting from SHANK3 deficiency. In one study ${ }^{97}$, the phosphoproteome of SHANK3-deficient rat cortical neurons was characterized, revealing an upregulation of CDC-like kinase 2 (CLK2) expression. Inhibition of CLK2 rescued social behaviour in mice carrying a mutation in Shank 3 exon 21, as well as synaptic deficits in SHANK3-deficient neurons and neurons derived from patient with PMS.

Together, these studies suggest that adult restoration of SHANK3 levels or restoration of downstream mediators may be a useful approach to alleviate some of the synaptic and behavioural impairments that are associated with SHANK3 mutations. Aligned with the idea of targeting downstream mediators and proteins associated with SHANK3 network, two groups have recently looked into mGluR5 and Homer as potential therapeutic targets in ASD. Using a complete Shank3-KO mouse ${ }^{36}$, it was shown that antagonism of mGluR5 activity ameliorates over-grooming behaviour, whereas positive allosteric modulation of mGluR5 exacerbates self-grooming. In a second study ${ }^{98}$, it was reported that a pharmacological increase in mGluR5 activity ameliorates over-grooming behaviour and rescues other behavioural deficits in Shank3-KO mouse. Although these studies might, at first, seem to be discrepant - the mGlu5R positive agonist CDPPB exacerbates and ameliorates self-grooming in the respective studies - it is crucial to note that these results were derived from different Shank3-mutant mouse lines. Furthermore, the results of the two studies were otherwise in agreement. In one study, CDPPB treatment slightly improved instrumental learning, normalized striatal long-term depression and slightly increased the protein level of two splice variants of Homer (Homer 1b and Homer 1c) in the striatum of complete Shank3-KO mouse $^{36}$. Similarly, in the other study ${ }^{98}$, a pharmacological increase in mGluR5 activity ameliorated functional deficits (NMDA-induced membrane depolarization) and behavioural defects (social interaction and Morris water maze performance) in mice with deleted exon 11. Nevertheless, these studies suggest that the defects in downstream signalling, and thus potential therapeutic targets (such as mGluR5 and Homer), that result from different mutations of the same gene might be very different.

In an unrelated study ${ }^{99}$, the authors reported a marked loss of cortical actin filaments in mice with deleted exon 11, which was associated with reduced RAC1 and PAK activity and increased cofilin activity (the major actin depolymerizing factor). This suggested that actin regulators might be another potential molecular target for the treatment of ASD. Elevation of RAC1 activity in the PFC of these mice rescued their social behaviour deficits and NMDAR hypofunction, whereas inhibition of PAK or RAC1 function induced social behaviour deficits and NMDAR hypofunction in wild-type mice.

The aforementioned demonstrations of pharmacological reversals of phenotypes in Shank3-mutant mice highlight potential target pathways that seem to converge with some pharmacological reversal studies carried out in Shank2-mutant mice. In those studies ${ }^{68,100}$, NMDA hypofunction was suggested to be a potential mechanism underlying ASD-like behaviours. By treating Shank2-mutant mice with D-cycloserine (a partial agonist of NMDAR), one study showed an improvement in social interaction that could also be attained by treating the mice with CDPPB (possibly because of the enhancement of NMDAR function through mGluR5 activation $)^{68}$. Similarly, another study used clioquinol (a zinc chelator and ionophore) to rescue social-interaction deficits in Shank2-mutant mice. It was suggested that clioquinol can be used to mobilize zinc towards postsynaptic sites, where it would then increase NMDAR function through tyrosine kinase SRC activation ${ }^{100}$. Alterations in NMDAR function and excitatory transmission could potentially lead to an E/I imbalance, as was also suggested by a recent study that showed impaired GABAergic neurotransmission in mice with deleted exon 6 and exon 7 (REF. 88). The study further demonstrated that administration of a $\mathrm{GABA}_{\mathrm{A}}$ receptor agonist can slightly improve the spatial-memory deficits observed in Shank2-mutant mice, although the social-interaction deficits cannot be rescued. Together these studies suggest that NMDAR hypofunction contributes to the development of some ASD-like phenotypes in Shank-mutant mice and that other related molecular targets could potentially be used to modulate NMDAR function and improve specific phenotypes.

\section{Conclusions and future perspectives}

Many important questions remain. Can we mitigate the loss of a missing SHANK protein by somehow upregulating other SHANK protein family members? Which of the domains of SHANK proteins are essential for their roles? Which cell types are more vulnerable to SHANK protein loss? 
Although most of the human SHANK mutations that underlie clinical conditions are heterozygous, the study and characterization of Shank homozygous mutant mice is sometimes essential, as it allows us to gain a clear understanding of the physiological role of a particular gene and the functional consequences of its disruption. Overall, three very important conclusions can be drawn from all the aforementioned studies. 'The earlier the better' seems to be the case in terms of therapeutic window; however, adult intervention may still be useful to alleviate some of the impairments that are associated with SHANK3 mutations. It is also clear that efforts need to be taken to understand Shank3 mutations in an isoform-specific manner. Finally, careful genotype-phenotype patient stratification is required before individual testing of specific pharmacological agents. Shank-mutant animal models, together with patient-derived induced pluripotent stem cells, will certainly help us to uncover some of the neurobiological secrets of SHANK proteins.
1. Sheng, M. \& Hoogenraad, C. C. The postsynaptic architecture of excitatory synapses: a more quantitative view. Annu. Rev. Biochem. 76, 823-847 (2007).

2. Ahmari, S. E. \& Smith, S. J. Knowing a nascent synapse when you see it. Neuron 34, 333-336 (2002).

3. Kano, M. \& Hashimoto, K. Synapse elimination in the central nervous system. Curr. Opin. Neurobiol. 19, 154-161 (2009)

4. Sheng, M. $\&$ Kim, E. The postsynaptic organization of synapses. Cold Spring Harb. Perspect. Biol. 3 , a005678 (2011)

5. Leblond, C. S. et al. Meta-analysis of SHANK mutations in autism spectrum disorders: a gradient of severity in cognitive impairments. PLoS Genet. 10 , e 1004580 (2014).

This study demonstrates a correlation between SHANK1, SHANK2 and SHANK3 mutations and the degree of cognitive impairment. The authors show that patients with SHANK3 mutations have more-severe cognitive deficits than those with SHANK1 or SHANK2 mutations and suggest SHANK mutation screening in clinical practice.

6. Gauthier, J. et al. Novel de novo SHANK3 mutation in autistic patients. Am. J. Med. Genet. $B$ Neuropsychiatr. Genet. 150, 421-424 (2009).

7. Boccuto, L. et al. Prevalence of SHANK3 variants in patients with different subtypes of autism spectrum disorders. Eur. J. Hum. Genet. 21, 310-316 (2013)

8. Sala, C., Vicidomini, C., Bigi, I., Mossa, A. \& Verpelli, C. Shank synaptic scaffold proteins: keys to understanding the pathogenesis of autism and other synaptic disorders. J. Neurochem. 135, 849-858 (2015).

9. Peça, J. et al. Shank3 mutant mice display autistic-like behaviours and striatal dysfunction. Nature $\mathbf{4 7 2}$ 437-442 (2011)

This study describes the first Shank3-mutant mice with PDZ domain deletion (exon 13 and exon 16 deletion). These mice show synaptic dysfunction and autism-related behavioural phenotypes such as impaired social interaction and stereotyped and/or repetitive behaviour.

10. Naisbitt, S. et al. Shank, a novel family of postsynaptic density proteins that binds to the NMDA receptor PSD-95/GKAP complex and cortactin. Neuron 23. 569-582 (1999).

This study provides the first description of the SHANK family of synaptic proteins.

11. Wang, X., Xu, Q., Bey, A. L., Lee, Y. \& Jiang, Y. Transcriptional and functional complexity of Shank3 provides a molecular framework to understand the phenotypic heterogeneity of SHANK3 causing autism and Shank3 mutant mice. Mol. Autism 5, 30 (2014).

This study addresses the functional and transcriptional regulation of different SHANK3 isoforms. The results suggest that different SHANK3 isoforms have distinct functions and that the different SHANK3 mutations found in patients with ASD disrupt only specific isoforms and result in distinct phenotypes.

12. Jiang, Y.-H \& Ehlers, M. D. Modeling autism by SHANK gene mutations in mice. Neuron $78,8-27$ (2013).

13. Beri, S. et al. DNA methylation regulates tissuespecific expression of Shank3. J. Neurochem. 101, 1380-1391 (2007)

14. Ching, T.-T. et al. Epigenome analyses using BAC microarrays identify evolutionary conservation of tissue-specific methylation of SHANK3. Nat. Genet 37, 645-651 (2005)
15. Maunakea, A. K. et al. Conserved role of intragenic DNA methylation in regulating alternative promoters. Nature 466, 253-257 (2010).

16. Lim, S. et al. Sharpin, a novel postsynaptic density protein that directly interacts with the shank family of proteins. Mol. Cell. Neurosci. 17, 385-397 (2001).

17. Böckers, T. M. et al. Synaptic scaffolding proteins in rat brain: ankyrin repeats of the multidomain Shank protein family interact with the cytoskeletal protein $\alpha$-fodrin. J. Biol. Chem. 276, 40104-40112 (2001).

18. Mameza, M. G. et al. SHANK3 gene mutations associated with autism facilitate ligand binding to the shank3 ankyrin repeat region. J. Biol. Chem. 288 26697-26708 (2013)

19. Uchino, S. et al. Direct interaction of post-synaptic density-95/DIg/ZO-1 domain-containing synaptic molecule Shank3 with GluR1 $\alpha$-amino-3-hydroxy-5-methyl-4-isoxazole propionic acid receptor. J. Neurochem. 97, 1203-1214 (2006)

20. Tu, J. C. et al. Coupling of mGluR/Homer and PSD-95 complexes by the Shank family of postsynaptic density proteins. Neuron 23, 583-592 (1999).

21. Hayashi, M. K. et al. The postsynaptic density proteins Homer and Shank form a polymeric network structure. Cell 137, 159-171 (2009).

22. Baron, M. K. et al. An architectural framework that may lie at the core of the postsynaptic density. Science 311, 531-535 (2006)

23. Boeckers, T. M. et al. C-Terminal synaptic targeting elements for postsynaptic density proteins ProSAP1/ Shank2 and ProSAP2/Shank3. J. Neurochem. 92 519-524 (2005)

24. Grabrucker, A. M. et al. Concerted action of zinc and ProSAP/Shank in synaptogenesis and synapse maturation. EMBO J. 30, 569-581 (2011).

25. Guilmatre, A., Huguet, G., Delorme, R. \& Bourgeron, T. The emerging role of SHANK genes in neuropsychiatric disorders. Dev. Neurobiol. 74, 113-122 (2014).

26. Boeckers, T. M., Bockmann, J., Kreutz, M. R. \& Gundelfinger, E. D. ProSAP/Shank proteins - a family of higher order organizing molecules of the postsynaptic density with an emerging role in human neurological disease. J. Neurochem. 81, 903-910 (2002)

27. Okamoto, P. M., Gamby, C., Wells, D., Fallon, J. \& Vallee, R. B. Dynamin isoform-specific interaction with the Shank/ProSAP scaffolding proteins of the postsynaptic density and actin cytoskeleton. J. Biol. Chem. 276, 48458-48465 (2001)

28. McWilliams, R. R., Gidey, E., Fouassier, L., Weed, S. A. $\&$ Doctor, R. B. Characterization of an ankyrin repeatcontaining Shank2 isoform (Shank2E) in liver epithelial cells. Biochem. J. 380, 181-191 (2004).

29. Leblond, C. S. et al. Genetic and functional analyses of SHANK2 mutations suggest a multiple hit model of autism spectrum disorders. PLoS Genet. 8, e 1002521 (2012).

30. Schmeisser, M. J. et al. Autistic-like behaviours and hyperactivity in mice lacking ProSAP1/Shank2. Nature 486, 256-260 (2012).

\section{This study describes one of the first} Shank2-mutant mice (exon 17 deletion; PDZ domain deletion). These mice show autism-related behavioural phenotypes and hyperactivity.

31. Lim, S. et al. Characterization of the Shank family of synaptic proteins. Multiple genes, alternative splicing, and differential expression in brain and development. J. Biol. Chem. 274, 29510-29518 (1999).

32. Peça, J., Ting, J. \& Feng, G. SnapShot: autism and the synapse. Cell 147, 706-706.e1 (2011).
33. Böckers, T. M. et al. Differential expression and dendritic transcript localization of Shank family members: identification of a dendritic targeting element in the 3' untranslated region of Shank 1 mRNA. Mol. Cell. Neurosci. 26, 182-190 (2004)

34. Zitzer, H., Hönck, H. H., Bächner, D., Richter, D. \& Kreienkamp, H. J. Somatostatin receptor interacting protein defines a novel family of multidomain proteins present in human and rodent brain. J. Biol. Chem. 274, 32997-33001 (1999)

35. Lee, J. et al. Shank3-mutant mice lacking exon 9 show altered excitation/inhibition balance, enhanced rearing, and spatial memory deficit. Front. Cell. Neurosci. 9, 94 (2015).

36. Wang, X. et al. Altered mGluR5-Homer scaffolds and corticostriatal connectivity in a Shank3 complete knockout model of autism. Nat. Commun. 7, 11459 (2016).

37. Mei, Y. et al. Adult restoration of Shank3 expression rescues selective autistic-like phenotypes. Nature 530 , 481-484 (2016).

This is the first report to show that adult restoration of the Shank3 gene selectively rescues certain synaptic defects and some autism-related behavioural phenotypes such as social interaction and stereotyped and/or repetitive behaviour in mice.

38. Lai, M. C. et al. Cognition in males and females with autism: similarities and differences. PLOS ONE 7 e47198 (2012)

39. Centers for Disease Control and Prevention. Prevalence of autism spectrum disorders - Autism and Developmental Disabilities Monitoring Network, 14 sites, United States, 2008. MMWR Surveill. Summ 61, 1-19 (2012)

40. American Psychiatric Association (eds). Diagnostic and Statistical Manual of Mental Disorders 5th edn (American Psychiatric Association Publishing, 2013).

41. Rosenberg, R. E. et al. Characteristics and concordance of autism spectrum disorders among 277 twin pairs. Arch. Pediatr. Adolesc. Med. 163, 907-914 (2009).

42. Geschwind, D. H. Advances in autism. Annu. Rev. Med. 60, 367-380 (2009)

43. Huguet, G., Ey, E. \& Bourgeron, T. The genetic landscapes of autism spectrum disorders. Annu. Rev. Genomics Hum. Genet. 14, 191-213 (2013).

44. Betancur, C. Etiological heterogeneity in autism spectrum disorders: more than 100 genetic and genomic disorders and still counting. Brain Res. 1380 42-77 (2011)

45. Toro, R. et al. Key role for gene dosage and synaptic homeostasis in autism spectrum disorders. Trends Genet. 26, 363-372 (2010).

46. Phelan, K. \& McDermid, H. E. The $22 q 13.3$ deletion syndrome (Phelan-McDermid syndrome) Mol. Syndromol. 2, 186-201 (2012).

47. Phelan, M. C. et al. 22013 deletion syndrome Am. J. Med. Genet. 101, 91-99 (2001).

48. Bonaglia, M. C. et al. Disruption of the ProSAP2 gene in a $t(12 ; 22)(q 24.1 ; q 13.3)$ is associated with the $22 q 13.3$ deletion syndrome. Am. J. Hum. Genet. 69 , 261-268 (2001).

This study is the first to describe a possible association between PMS and disruption of the SHANK3 gene.

49. Bonaglia, M. C. et al. Molecular mechanisms generating and stabilizing terminal $22 q 13$ deletions in 44 subjects with phelan/mcdermid syndrome. PLoS Genet. 7, e1002173 (2011).

50. Wilson, H. L. et al. Molecular characterisation of the $22 q 13$ deletion syndrome supports the role of haploinsufficiency of SHANK3/PROSAP2 in the major neurological symptoms. J. Med. Genet. 40, 575-584 (2003). 
51. Wilson, H. L. et al. Interstitial $22 q 13$ deletions: genes other than SHANK3 have major effects on cognitive and language development. Eur. J. Hum. Genet. 16 1301-1310 (2008)

52. Moessner, R. et al. Contribution of SHANK3 mutations to autism spectrum disorder. Am. J. Hum Genet. 81, 1289-1297 (2007).

53. Durand, C. M. et al. Mutations in the gene encoding the synaptic scaffolding protein SHANK3 are associated with autism spectrum disorders. Nat. Genet. 39, 25-27 (2007).

54. Berkel, S. et al. Mutations in the SHANK2 synaptic scaffolding gene in autism spectrum disorder and mental retardation. Nat. Genet. 42, 489-491 (2010).

55. Okabe, S. Molecular anatomy of the postsynaptic density. Mol. Cell. Neurosci. 34, 503-518 (2007).

56. Emes, R. D. \& Grant, S. G. N. Evolution of synapse complexity and diversity. Annu. Rev. Neurosci. 35, 111-131 (2012).

57. Boeckers, T. M. The postsynaptic density. Cell Tissue Res. 326, 409-422 (2006).

58. Montgomery, J. M., Zamorano, P. L. \& Garner, C. C. MAGUKs in synapse assembly and function: an emerging view. Cell. Mol. Life Sci. 61, 911-929 (2004).

59. Sheng, M. \& Kim, E. The Shank family of scaffold proteins. J. Cell Sci. 113, 1851-1856 (2000).

60. Tao-Cheng, J. H., Dosemeci, A., Gallant, P. E., Smith, C. \& Reese, T. Activity induced changes in the distribution of Shanks at hippocampal synapses. Neuroscience 168, 11-17 (2010).

61. Tao-Cheng, J. H., Yang, Y., Reese, T. S. \& Dosemeci, A. Differential distribution of shank and GKAP at the postsynaptic density. PLOS ONE 10, e0118750 (2015).

62. Wang X et al Synaptic dysfunction and abnormal behaviors in mice lacking major isoforms of Shank3. Hum. Mol. Genet. 20, 3093-3108 (2011).

63. Bozdagi, O. et al. Haploinsufficiency of the autismassociated Shank3 gene leads to deficits in synaptic function, social interaction, and social communication. Mol. Autism 1, 15 (2010).

This study describes the first Shank3-mutant mice (exon 4 and exon 9 deletion). These mice show some ASD-relevant phenotypes.

64. Yang, M. et al. Reduced excitatory neurotransmission and mild autism-relevant phenotypes in adolescent Shank3 null mutant mice. J. Neurosci. 32, 6525-6541 (2012).

65. Kouser, M. et al. Loss of predominant Shank3 isoforms results in hippocampus-dependent impairments in behavior and synaptic transmission. J. Neurosci. 33, 18448-18468 (2013).

66. Zhou, Y. et al. Mice with Shank3 mutations associated with ASD and schizophrenia display both shared and distinct defects. Neuron 89, 147-162 (2016).

67. Hung, A. Y. et al. Smaller dendritic spines, weaker synaptic transmission, but enhanced spatial learning in mice lacking Shank 1. J. Neurosci. 28, 1697-1708 (2008).

This study describes the first Shank 1 -mutant mice (exon 14 and exon 15 deletion; PDZ domain deletion).

68. Won, H. et al. Autistic-like social behaviour in Shank2-mutant mice improved by restoring NMDA receptor function. Nature 486, 261-265 (2012). This study describes one of the first Shank2-mutant mice (exon 6 and exon 7 deletion). These mice show autism-related behavioural phenotypes and NMDAR dysfunction.

69. Roussignol, G. et al. Shank expression is sufficient to induce functional dendritic spine synapses in aspiny neurons. J. Neurosci. 25, 3560-3570 (2005)

70. Sala, C. et al. Regulation of dendritic spine morphology and synaptic function by Shank and Homer. Neuron 31, 115-130 (2001).
71. Peixoto, R., Wang, W., Croney, D., Kozorovitskiy, Y. \& Sabatini, B. Early hyperactivity and precocious maturation of corticostriatal circuits in Shank3B-1 mice. Nat. Neurosci. 19, 716-724 (2016).

72. Yi, F. et al. Autism-associated SHANK3 haploinsufficiency causes $I$ channelopathy in human neurons. Science 352, aaf2669 (2016).

73. Shcheglovitov, A. et al. SHANK3 and IGF1 restore synaptic deficits in neurons from $22 q 13$ deletion syndrome patients. Nature 503, 267-271 (2013).

74. Gogolla, N., Takesian, A. E., Feng, G., Fagiolini, M. \& Hensch, T. K. Sensory integration in mouse insular cortex reflects GABA circuit maturation. Neuron $\mathbf{8 3}$ 894-905 (2014).

75. Filice, F., Vörckel, K. J., Sungur, A. Ö., Wöhr, M. \& Schwaller, B. Reduction in parvalbumin expression not loss of the parvalbumin-expressing GABA interneuron subpopulation in genetic parvalbumin and shank mouse models of autism. Mol. Brain 9, 10 (2016).

76. Lu, C. et al. Micro-electrode array recordings reveal reductions in both excitation and inhibition in cultured cortical neuron networks lacking Shank3. Mol. Psychiatry 21, 159-168 (2015).

77. Rubenstein, J. L. R. \& Merzenich, M. M. Model of autism: increased ratio of excitation/inhibition in key neural systems. Genes Brain Behav. 2, 255-267 (2003).

78. Bourgeron, T. A synaptic trek to autism. Curr. Opin Neurobiol. 19, 231-234 (2009).

79. Bernhardt, B. C. \& Singer, T. The neural basis of empathy. Annu. Rev, Neurosci. 35, 1-23 (2012).

80. Frith, C. D. The social brain? Phil. Trans. R. Soc. B 362, 671-678 (2007)

81. Lamm, C. \& Singer, T. The role of anterior insular cortex in social emotions. Brain Struct. Funct. 214 579-591 (2010).

82. Barak, B. \& Feng, G. Neurobiology of social behavior abnormalities in autism and Williams syndrome. Nat. Neurosci. 19, 647-655 (2016)

83. Gauthier, J. et al. De novo mutations in the gene encoding the synaptic scaffolding protein SHANK3 in patients ascertained for schizophrenia. Proc. Natl Acad. Sci. USA 107, 7863-7868 (2010).

84. Han, K. et al. SHANK3 overexpression causes manic like behaviour with unique pharmacogenetic properties. Nature 503, 72-77 (2013) This study shows that mice with SHANK3 overexpression exhibit synaptic dysfunction and manic-like phenotypes, thus reinforcing the idea that proper Shank3 gene dosage is crucial.

85. Silverman, J. L. et al. Sociability and motor functions in Shank1 mutant mice. Brain Res. 1380, 120-137 (2011)

86. Mao, W. et al. Shank 1 regulates excitatory synaptic transmission in mouse hippocampal parvalbuminexpressing inhibitory interneurons. Eur. J. Neurosci. 41, 1025-1035 (2015).

87. Wöhr, M., Roullet, F. I., Hung, A. Y., Sheng, M. \& Crawley, J. N. Communication impairments in mice lacking shank 1: reduced levels of ultrasonic vocalizations and scent marking behavior. PLOS ONE 6, e20631 (2011).

88. Lim, C.-S. et al. Enhancing inhibitory synaptic function reverses spatial memory deficits in Shank2 mutant mice. Neuropharmacology 112, 104-112 (2017)

89. Peter, S. et al. Dysfunctional cerebellar Purkinje cells contribute to autism-like behaviour in Shank2-deficient mice. Nat. Commun. 7, 12627 (2016).

90. Lord, C., Cook, E. H., Leventhal, B. L. \& Amaral, D. C. Autism spectrum disorders. Neuron 28, 355-363 (2000)

91. Amaral, D., Geschwind, D. \& Dawson, G. Autism Spectrum Disorders (Oxford Univ. Press, 2011).
92. Swiech, L. et al. In vivo interrogation of gene function in the mammalian brain using CRISPR-Cas9. Nat Biotechnol. 33, 102-106 (2014).

93. Guy, J., Gan, J., Selfridge, J., Cobb, S. \& Bird, A. Reversal of neurological defects in a mouse model of Rett syndrome. Science 315, 1143-1147 (2007). This study shows for the first time a robust phenotypic reversal, both in immature and in mature adult animal models of Rett syndrome, by induced expression of MeCP2.

94. Garg, S. K. et al. Systemic delivery of MeCP2 rescues behavioral and cellular deficits in female mouse models of Rett syndrome. J. Neurosci. 33 , 13612-13620 (2013).

95. Sztainberg, Y. et al. Reversal of phenotypes in MECP2 duplication mice using genetic rescue or antisense oligonucleotides. Nature 528, 123-126 (2015).

96. Clement, J. P. et al. Pathogenic SYNGAP1 mutations impair cognitive development by disrupting maturation of dendritic spine synapses. Cell 151 709-723 (2012).

97. Bidinosti, M. et al. CLK2 inhibition ameliorates autistic features associated with SHANK3 deficiency. Science 351, 1199-1203 (2016).

98. Vicidomini, C. et al. Pharmacological enhancement of mGlu5 receptors rescues behavioral deficits in SHANK3 knock-out mice. Mol. Psychiatry http://dx. doi.org/10.1038/mp.2016.30 (2016).

99. Duffney, L. J. et al. Autism-like deficits in Shank3-deficient mice are rescued by targeting actin regulators. Cell Rep. 11, 1400-1413 (2015).

100. Lee, E.-J. et al. Trans-synaptic zinc mobilization improves social interaction in two mouse models of autism through NMDAR activation. Nat. Commun. 6 7168 (2015).

101. Jaramillo, T. C. et al. Altered striatal synaptic function and abnormal behaviour in Shank3 Exon4-9 deletion mouse model of autism. Autism Res. 9, 350-375 (2016).

102. Speed, H. E. et al. Autism-associated insertion mutation (InsG) of Shank3 Exon 21 causes impaired synaptic transmission and behavioral deficits. J. Neurosci. 35, 9648-9665 (2015).

\section{Acknowledgements}

The authors thank N. Chen for critical comments and editing the manuscript, N. Sousa (Minho University, Portugal) and all members of the Feng laboratory for support and helpful discussion. Research related to this work in the laboratory of G.F. is supported by the Poitras Center for Affective Disorders Research at the Massachusetts Institute of Technology (MIT), Stanley Center for Psychiatric Research at Broad Institute of MIT and Harvard, National Institute of Mental Health (MH097104), Nancy Lurie Marks Family Foundation, Simons Foundation Autism Research Initiative (SFARI grant 178130) and Simons Center for the Social Brain at MIT. P.M. is sup ported by Society in Science, The Branco Weiss Fellowship administered by Eidgenössische Technische Hochschule (ETH) Zürich, and European Molecular Biology Organization (EMBO) Long-Term Fellowship (ALTF 89-2016).

\section{Competing interests statement}

The authors declare no competing interests.

FURTHER INFORMATION

UniProt Knowledgebase: http://www.uniprot.org/

National Center for Biotechnology Information (NCBI)

database: https://www.ncbi.nlm.nih.gov/

SUPPLEMENTARY INFORMATION

See online article: $\underline{\mathrm{S1}}$ (figure) | $\underline{\mathrm{S}}$ (figure) $\mid \underline{\mathrm{S} 3}$ (figure) $\mid \underline{\mathrm{S}}$

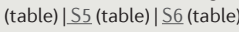

ALL LINKS ARE ACTIVE IN THE ONLINE PDF 